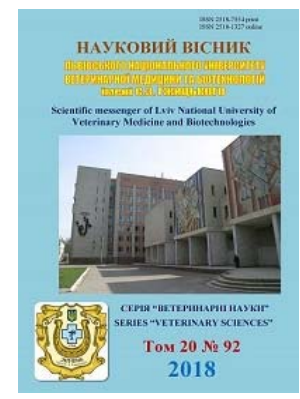

\author{
Науковий вісник Дьвівського національного університету \\ ветеринарної медицини та біотехнологій імені С.3. Гжицького
}

\author{
Scientific Messenger of Lviv National University \\ of Veterinary Medicine and Biotechnologies
}

UDC 619.615.637

\title{
Investigation of the parameters of acute and acute toxicity of the "VetMicoDerm" liniment under the skin application
}

\author{
V. Martynyshyn \\ Stepan Gzhytskyi National University of Veterinary Medicine and Biotechnologies Lviv, Ukraine
}

Article info

Received 16.10.2018

Received in revised form 16.11 .2018

Accepted 19.11.2018

Stepan Gzhytskyi National University of Veterinary Medicine and Biotechnologies Lviv,

Pekarska Str., 50, Lviv, 79010, Ukraine.

Tel.: +38-097-519-13-88

E-mail:doctorvetlviv@ukr.net

\begin{abstract}
Martynyshyn, $V$. (2018). Investigation of the parameters of acute and acute toxicity of the "VetMicoDerm" liniment under the skin application. Scientific Messenger of Lviv National University of Veterinary Medicine and Biotechnologies, 20(92), 59-63. doi: 10.32718/nvlvet9212
\end{abstract}

The toxicity parameters of "VetMikoDerm" for one-time and long-term skin treatment were investigated. The studied liniment as an off-white substance has a thio derivative of 1,2,4-triasole. Spotted thistle oil is used as a solvent. The research of the determination of acute and low acute skin toxicity has been performed on young, healthy, healthy skin of the laboratory rats. The drug was applied in different doses to the stripped areas of the skin (area is not less than 10\% of the total area of the skin). It was established that after a single application of the drug (24 hours) in a dose of less than $2000 \mathrm{mg} / \mathrm{kg}$ of body weight, the death of experimental animals or any signs of general intoxication of the body is not observed. Local reaction (redness, itching, allergy, combing) is absent. According to GHS under the assessment in this dose studying the "VetMicoDerm" drug belongs to the 5th safety category (Grade 5, not classified). During a long-lasting application of the drug (28 days), the death of the rats was not adversed, the animals had a preserved appetite, responded adequately to external stimuli, reflex excitability was completely preserved. Under hematological and biochemical studies of blood of the experimental animals, it was found that against the backdrop of insignificant increase in the number of white blood cells in their blood, the number of neutrophils increases and the percentage of lymphocytes decreases significantly. However, under the usage of the drug in the therapeutic dose $(50 \mathrm{mg} / \mathrm{kg}$ body weight) the liver function has a tendency to increase. Increasing in dose $(500 \mathrm{mg} / \mathrm{kg}$ ) of the VetMikoDerm a 10-fold continued its application which led to an increase in serum concentrations of urea and creatinine, increasing the mass index can serve as a marker of renal decline functional condition of the body.

Key words: acute and subacute toxicity, rats, "VetMikoDerm", hematological and biochemical parameters of blood.

\section{Дослідження параметрів гострої і підгострої токсичності лініменту "ВетМікоДерм" за нашкірного застосування}

\author{
В.П. Мартинишин
}

Львівський національний університет ветеринарної медицини та біотехнологій імені С.З. Гжицького, м. Львів, Україна

\footnotetext{
Досліджено параметри токсичності препарату “ВетМікоДерм” за одноразового і довготривалого нашкірного його застосування. Досліджуваний лінімент як діюча речовина має тіопохідну 1,2,4-тріазолу, а за розчинник в ньому використано олію розторопші плямистої. Дослідження з визначення гострої і підгострої нашкірної токсичності проведено на молодих, здорових із непошкодженою шкірою лабораторних щурах. Препарат наносився в різних дозах на вистрижені ділянки шкіри (площа не менше 10\% від загальної площі шкіри). Встановлено, шчо за одноразової аплікачії препарату (24 год) в дозі меншій за 2000 мг/кг маси тіла загибелі піддослідних тварин чи появи в них ознак загальної інтоксикації організму не спостерігалося. Місцева реакція (почервоніння, свербіж, алергія, розчухування) відсутня. 3 урахуванням вимог УГС (GHS) досліджуваний препарат “ВетМікоДерм”, за проведеною оцінкою в такій дозі належить до 5-ї категорії (5 клас, не класифікується) безпечності. За довготривалого нашкірного застосування препарату (28 діб) загибель иурів не наступала, тварини мали збережений апетит, адекватно реагували на зовніині подразники, рефлекторна збудливість була повністю збережена. За гематологічних та біохімічних досліджень крові в піддослідних тварин встановлено, щуо на тлі незначного зростання в їх крові числа лейкочитів підвищується кількість нейтрофілів та
} 
вірогідно знижується відсоток лімфоцитів. Протеїнсинтезувальна функиія печінки за використання препарату в терапевтичній дозі (50 мг/кг маси тварини) мала тенденцію до зростання. За 10-ти кратного збільшення дози (500 мг/кг) ВетМікоДерму тривала його аплікація призводила до підвищення в сироватці крові концентрації сечовини і креатиніну, цио на тлі зростання індексу маси нирок може слугувати маркером зниження функціонального стану изього органа.

Ключові слова: гостра і підгостра токсичність, щурі, “ВетМікоДерм”, гематологічні і біохімічні показники крові.

Вступ

Серед синтетичних біологічно активних сполук, які за хімічною структурою $є$ гетероциклічними речовинами 3 атомом нітрогену, існує значна кількість препаратів, які знайшли своє застосування як в медицині, так і у ветеринарній практиці. Особливу увагу серед подібних речовин привертають похідні 1,2,4тріазолу (Obushak et al., 2003; Panasenko, 2005; Savchenkova, 2008).

Серед різноманітних патологій, що трапляються в домашніх і свійських тварин особливого поширення набувають захворювання шкіри. Більшість 3 них мають хронічний перебіг та погано піддаються лікуванню. Підвищити ефективність лікування тварин 3 дерматитами чи іншою нашкірною патологією вдається за умови використання багатокомпонентних мазей чи лініментів. Наявні наукові повідомлення, що використання м'яких лікарських форм 3 морфоліній 2-[5(піридин-4-іл)-1,2,4-тріазол-3-ілтіо] ацетатом, піреридиній 2-[5-(фуран-2-іл)-4-метил-1,2,4-тріазол-3-ілтіо] ацетатом призводить до пришвидшення лікування дерматитів у собак (Knysh et al., 2010).

Цінними, на нашу думку, є лініменти, що виготовляються за типом розчинів на нелетких розчинниках, зокрема рослинних оліях. При створенні нового препарату 3 потенційно вираженою протимікробною i протигрибковою дією нами досліджується субстанція на основі тіопохідних тріазолу, синтезована в лабораторії кафедри фармакології Запорізького державного медичного університету. Як розчинник або основа для лініменту було використано олію розторопші плямистої, яка за даними літератури є не лише доброю дисперсною системою для діючих речовин, а й самостій- но проявляє виражені мембраностабілізувальні, протизапальні та ранозагоюючі властивості (Martynyshyn et al., 2017).

Фармакологічна активність похідних 1,2,4тріазолу є загальновідомою. Однак здатність синтетичних сполук до прояву побічних і токсичних ефектів вимагає детальних досліджень щодо з'ясування параметрів гострої і хронічної токсичності досліджуваних компонентів препарату (Kosenko et al., 1997; Kotsiumbas et al., 2006; Todoriuk et al., 2018).

Тому метою нашої роботи були встановлення безпечності препарату "ВетМікоДерм" за умови однократного і довготривалого його нашкірного примінення.

\section{Матеріал і методи досліджень}

Дослідження 3 визначення гострої нашкірної токсичності лініменту ВетМікоДерм проводили відповідно до вимог ОЕСД № 402 (OECD, 2017). Для досліду використовували здорових, молодих щурів 3 непошкодженою шкірою, масою тіла 200-220 г.

За день до нанесення досліджуваного засобу проводили видалення шерсті з дорзальної/бокової поверхні шкіри (10\% від загальної площі поверхні тіла). Лінімент "ВетМікоДерм" наносили якомога рівніше i тримали в контакті зі шкірою за допомогою пористої марлевої пов'язки та неподразливої стрічки впродовж 24 годин. Згідно з методикою (OECD, 1981), у зв'язку 3 відсутностю інформацї щодо досліджуваної речовини, ВетМікоДерм наносили у початковій дозі 200 мг/кг маси тіла тварини. Усі подальші дослідження проводили відповідно до блок-схеми (рис. 1).

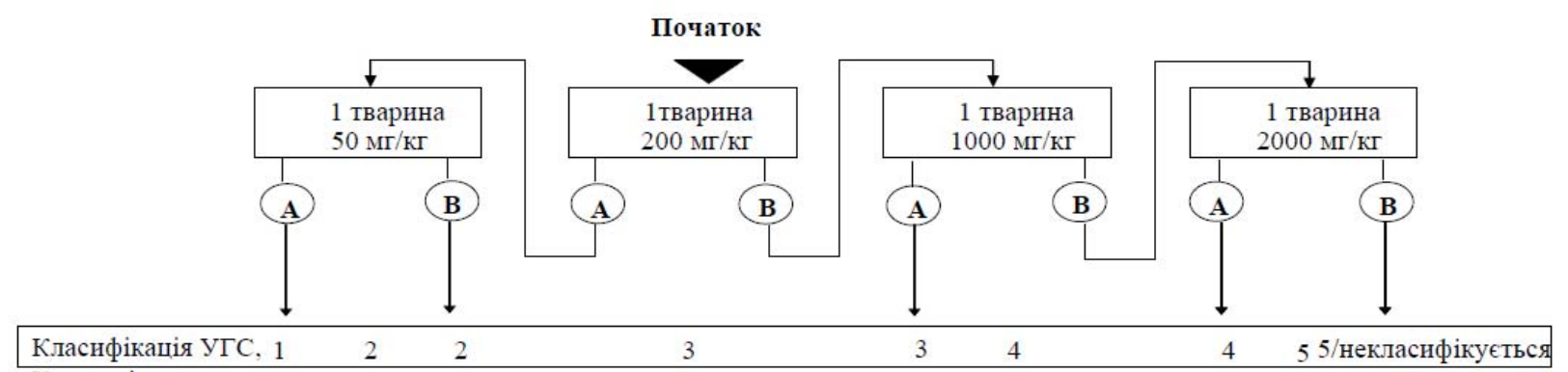

Категорія

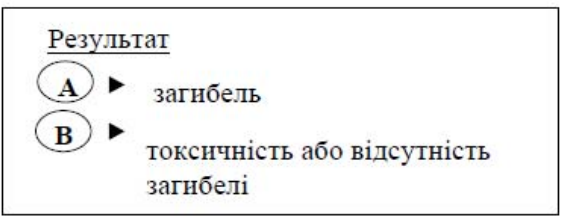

Рис. 1. Дослідження діапазону дози препарату “ВетМікоДерм” 
Після нанесення препарату “ВетМікоДерм” спостереження за лабораторними тваринами вели протягом 14 діб. При цьому враховували зовнішній вигляд і поведінку тварин, стан їх шерсті, видимих слизових оболонок, відношення до корму, ритм і частоту дихання, час виникнення та характер інтоксикації, іiі важкість, перебіг, час загибелі тварин або їх одужання.

Вивчення нашкірної токсичності ВетМікоДерму за тривалого застосування здійснювали відповідно до ОЕСД № 410 (Repeated Dose Dermal Toxicity: 21/28day Study). Для досліду використовували молодих здорових тварин з непошкодженою шкірою, масою тіла 200-220 г. За день до нанесення досліджуваного засобу, як і в попередньому досліді, проводили видалення шерсті з повторенням через тиждень.

Досліджуваний засіб тримали в контакті зі шкірою щоденно впродовж 6 годин. Досліджуваний лінімент наносили на шкіру кожного дня впродовж 28 діб. Після закінчення періоду експозиції досліджуваний засіб видаляли, де це можливо, використовуючи при цьому воду чи інший відповідний розчинник.

Для досліду, за принципом аналогів, було сформовано 3 групи тварин - по 6 щурів у кожній. Тваринам контрольної групи на попередньо підготовлену ділянку шкіри наносили розчин олії розторопші плямистої, дослідної групи - препарат в дозі 50 мг/кг, а II дослідної групи - 500 мг/кг маси тіла.

На наступну добу після закінчення досліду щодо вивчення підгострої токсичності препарату "ВетМікоДерм” лабораторних тварин за легкого ефірного наркозу піддавали декапітації, відбирали проби крові та проводили відповідні гематологічні й біохімічні її дослідження за загальновизнаними методиками. Крім того, тварин розтинали, зважували масу внутрішніх органів, визначали коефіцієнти їхньої маси, порівняно 3 тваринами контрольної групи.

\section{Результати та їх обговорення}

За проведення експериментів на білих щурах встановлено, що нашкірне нанесення "ВетМікоДерму” у дозі 2000мг/кг маси тіла не викликало загибелі дослідних тварин чи появи в них якихось ознак загальної інтоксикації організму. При цьому в місці контакту препарату зі шкірою ознак почервоніння, свербіжу, розчухування не виявлено. 3 урахуванням вимог УГС (GHS) - узгодженої на глобальному рівні системи класифікації небезпеки та маркування хімічної продукції, досліджуваний лінімент "ВетМікоДерм" належить до 5-ї категорії (клас 5, не класифікується).

За проведення довготривалого досліду з вивчення підгострої токсичності встановлено, що впродовж усього періоду спостереження дослідні тварини були активними, мали задовільний апетит, адекватно реагували на звукові та світлові подразники, у них зберігалась виражена рефлекторна збудливість. Загибелі піддослідних щурів чи ознак токсикозу, викликаного тривалим контактом новоствореного лікарського засобу із шкірою, виявлено не було.

За оцінкою морфологічних показників крові встановлено, що за довготривалого нанесення ВетМікоДерму на шкіру лабораторних тварин в терапевтичній та 10-ти кратній терапевтичній дозах суттєвих змін в кількості еритроцитів, концентрації гемоглобіну та відносних показниках, що характеризують насиченість еритроцитів гемоглобіном (MCHC, MCH, MCV), не відзначено (табл. 1). При цьому число лейкоцитів у крові щурів I і II дослідних груп мало виражену тенденцію до зниження. Аналіз лейкограми показав, що в них на тлі лейкоцитозу відзначено вірогідне зниження кількості лімфоцитів на 10,5 і 8,8\% (P < 0,05) та зростання відсотка нейтрофілів на 27,2 і 25,1\% відповідно. Число моноцитів та еозинофілів суттєво не змінювалось і було на рівні показника щурів контрольної групи.

\section{Таблиця 1}

Гематологічні показники крові білих щурів на 29- ту добу досліду за нашкірного застосування лініменту ВетМікоДерм $(\mathrm{M} \pm \mathrm{m}, \mathrm{n}=6)$

\begin{tabular}{|c|c|c|c|c|}
\hline \multirow{3}{*}{\multicolumn{2}{|c|}{ Показники }} & \multicolumn{3}{|c|}{ Групи тварин } \\
\hline & & \multirow{2}{*}{ Контрольна } & \multicolumn{2}{|c|}{ дослідні } \\
\hline & & & $\mathrm{I}-\mathrm{a}$ & II-a \\
\hline \multicolumn{2}{|l|}{ Гемоглобін, г/л } & $147,75 \pm 4,78$ & $145,17 \pm 1,54$ & $150,0 \pm 1,14$ \\
\hline \multicolumn{2}{|c|}{ Еритроцити, Т/л } & $6,35 \pm 0,25$ & $6,25 \pm 0,11$ & $6,52 \pm 0,11$ \\
\hline \multicolumn{2}{|c|}{ Лейкоцити, Г/л } & $10,47 \pm 1,99$ & $8,63 \pm 2,34$ & $7,88 \pm 0,60$ \\
\hline \multicolumn{2}{|l|}{ Гематокрит, \% } & $40,5 \pm 0,89$ & $40,17 \pm 0,28$ & $41,4 \pm 0,39$ \\
\hline \multirow{4}{*}{$\begin{array}{l}\text { Лейкограма, } \\
\text { \% }\end{array}$} & Нейтрофіли & $19,5 \pm 1,54$ & $24,8 \pm 1,85^{*}$ & $24,4 \pm 1,94$ \\
\hline & Лімфоцити & $71,5 \pm 0,5$ & $64,0 \pm 2,28^{*}$ & $65,2 \pm 2,06^{*}$ \\
\hline & Моноцити & $9 \pm 0,58$ & $9,6 \pm 0,75$ & $9,2 \pm 0,49$ \\
\hline & Еозинофіли & $0 \pm 0$ & $1 \pm 0,7$ & $1,2 \pm 0,49$ \\
\hline \multicolumn{2}{|l|}{ МCH, пг } & $23,18 \pm 0,19$ & $23,1 \pm 0,42$ & $22,88 \pm 0,29$ \\
\hline \multicolumn{2}{|l|}{ MCHC, г/дл } & $36,48 \pm 0,44$ & $36,15 \pm 0,18$ & $36,24 \pm 0,27$ \\
\hline \multicolumn{2}{|l|}{$\mathrm{MCV}$, мкм $^{3}$} & $63,63 \pm 1,23$ & $63,93 \pm 1,18$ & $63,12 \pm 0,45$ \\
\hline \multicolumn{2}{|c|}{ Тромбоцити, Г/л } & $707,75 \pm 66,14$ & $805,5 \pm 42,33^{*}$ & $737,2 \pm 92,82$ \\
\hline
\end{tabular}

Примітка: в цій та інших таблицях *- $\mathrm{P}<0,05 ; * *-\mathrm{P}<0,01 ; * * *-\mathrm{P}<0,001$

Аналіз окремих біохімічних показників сироватки крові піддослідних тварин наведено в таблиці 2.
Нами встановлено, що ВетМікоДерм в дозі 50 і 500 мг/кг маси тіла (дослідні групи I і II) за тривалого зовнішнього застосування сприяє поліпшенню проте- 
їнсинтезувальних процесів у лабораторних щурів. Рівень загального протеїну в сироватці крові щурів дослідних груп був на 9,9 і 4,6\% вищим за показник тварин контрольної групи.

У щурів 2-ї дослідної групи відзначено вірогідне зростання концентрації сечовини в сироватці крові на $32,1 \%(\mathrm{P}<0,01)$ та рівня креатиніну на $10,0 \%(\mathrm{P}<$ 0,05). Вірогідне збільшення в крові щурів цієї групи креатиніну, на тлі зростання вагового коефіцієнту маси нирок $\epsilon$, ймовірно, ознакою зниження функціонального стану цього органа.

Вагові коефіцієнти внутрішніх органів щурів дослідних груп, що являють собою співвідношення їхньої маси до маси тіла не зазнавали суттєвих відхилень, порівняно 3 аналогічним показником тварин контрольної групи, хоч у щурів I групи, за аплікації їм досліджуваного лініменту в дозі 50мг/кг відзначено тенденцію до зростання індексу маси печінки, селезінки, серця, нирок і тимуса (табл. 3).

\section{Таблиця 2}

Біохімічні показники крові білих щурів на 29-ту добу досліду за нашкірного застосування ВетМікоДерм $(\mathrm{M} \pm \mathrm{m}, \mathrm{n}=6)$

\begin{tabular}{|c|c|c|c|}
\hline \multirow{2}{*}{ Показники } & \multirow{2}{*}{ Контрольна (К) } & \multicolumn{2}{|c|}{ Дослідні (Д) } \\
\hline & & $\mathrm{I}-\mathrm{a}$ & II-a \\
\hline Протеїн загальний, г/л & $73,87 \pm 1,90$ & $81,2 \pm 2,67$ & $77,3 \pm 1,87$ \\
\hline Сечовина, ммоль/л & $7,55 \pm 0,48$ & $8,23 \pm 0,61$ & $9,97 \pm 0,32 * *$ \\
\hline Креатинін, мкмоль/л & $73,7 \pm 3,04$ & $77,4 \pm 4,0$ & $81,1 \pm 3,22 *$ \\
\hline АсАТ, Од/л & $93,0 \pm 14,0$ & $70,95 \pm 5,09$ & $77,18 \pm 4,76$ \\
\hline АлАТ, Од/л & $243,2 \pm 18,99$ & $240,75 \pm 21,88$ & $240,4 \pm 28,09$ \\
\hline ЛФ, Од/л & $179,85 \pm 10,51$ & $211,63 \pm 8,898$ & $197,03 \pm 16,05$ \\
\hline
\end{tabular}

Таблиця 3

Вагові коефіцієнти маси внутрішніх органів білих щурів на 29-ту добу досліду $(\mathrm{M} \pm \mathrm{m}, \mathrm{n}=6)$

\begin{tabular}{crrr}
\hline & & \multicolumn{1}{c}{ Групи тварин } \\
\cline { 2 - 4 } Внутрішні органи & контрольна & $37,7 \pm 1,31$ & І група \\
\cline { 2 - 4 } & $33,5 \pm 2,22$ & $2,59 \pm 0,08$ & $31,35 \pm 0,81$ \\
Печінка & $2,25 \pm 0,17$ & $3,87 \pm 0,11$ & $3,74 \pm 0,18$ \\
Селезінка & $3,61 \pm 0,19$ & $8,02 \pm 0,74$ & $3,99 \pm 1,83$ \\
Серце & $8,36 \pm 0,63$ & $3,35 \pm 0,04$ & $3,48 \pm 0,11$ \\
Легені & $3,21 \pm 0,14$ & $3,41 \pm 0,09$ & $1,49 \pm 0,13$ \\
Права нирка & $3,11 \pm 0,24$ & $1,49 \pm 0,24$ & $217,0 \pm 6,44$ \\
Ліва нирка & $1,29 \pm 0,10$ & $229,6 \pm 4,69$ \\
Тимус & $224,5 \pm 5,5$ & & \\
Маса тіла тварин, г & &
\end{tabular}

Отже, аналізуючи отримані дані щодо дії препарату “ВетМікоДерм”, варто зазначити, що довготривале нашкірне його застосування викликало у тварин незначне підвищення відсотка нейтрофілів на тлі зниження лімфоцитів, що, ймовірно, може свідчити про регенеративну реакцію шкіри на дію препарату. Зростання вмісту сечовини в сироватці крові та рівня креатиніну, за збільшення маси нирок характеризує функціональний стан нирок, і найімовірніше, адаптаційно-пристосувальний характер.

\section{Висновки}

1. Одноразове застосування лініменту "ВетМікоДерм” не викликає загибелі тварин, появи токсичних явищ, почервоніння на місці нанесення препарату, тому згідно з УГС (GHS) досліджуваний засіб належить до 5 категорії (клас 5, не класифікується).

2. Довготривале нашкірне застосування лініменту “ВетМікоДерм" викликає зростання кількості нейтрофілів та особливо в 10-ти кратній терапевтичній дозі зниження відсотка лімфоцитів, сприяє підвищенню протеїносинтезувальної функції печінки та пригнічує функціональний стан нирок.
Перспектива подальших досліджень. Буде вивчено дію препарату “ВетМікоДерм” за дерматитів грибкового походження.

\section{References}

Obushak, N.D., Matijchuk V.S., \& Martjak R.L. (2003). Sintez geterociklov na osnove produktov anionarilirovanija nepredel'nyh soedinenij. Produkty galogenarilirovanija akrilovoj kisloty $\mathrm{i}$ ee jefirov $\mathrm{v}$ sinteze proizvodnyh benzo[v] tiofena. Himija geterocik-licheskih soedinenij, 7, 1019-1026 (in Russian).

Panasenko, O.I. (2005). Syntez, peretvorennia, fizykokhimichni ta biolohichni vlastyvosti pokhidnykh 1,2,4-triazolu: dys. d-ra farm. nauk. K., 396 (in Ukrainian).

Savchenkova, L.V. (2008). Klinichna farmakolohiia tiotriazolinu: (ohliad lit-ry). Ukr. med. almanakh, 11(3), 212-217 (in Ukrainian).

Knysh, Ye.H., Parchenko, V.V., \& Panasenko, O.I. (2010). Maz dlia korektsii perebihu zapalnykh protsesiv. Patent Ukrainy na korysnu model 90983.Zaiav. 12.10.2009; opubl. 10.06.2010, Biul. № 
11. http://uapatents.com/4-90983-maz-dlya-korekciperebigu-zapalnikh-procesiv.html (in Ukrainian).

Knysh, Ye.H., Parchenko, V.V., \& Panasenko, O.I. (2010). Hidrofilna maz dlia likuvannia zapalen shkiry. Patent Ukrainy na korysnu model 47942. Zaiav. 12.10.09; opubl. 25.02.2010, Biul. № 4 . http://uapatents.com/3-47942-gidrofilna-maz-dlyalikuvannya-zapalen-shkiri.html (in Ukrainian).

Martynyshyn, V.P., Hunchak, V.M., Hutyi, B.V., \& Hlukh, O.S. (2017). Do metodyky pryhotuvannia linimentu na osnovi tiopokhidnoi triazolu ta yoho otsinka za fizychnymy vlastyvostiamy i diieiu na okremi mikroorhanizmy ta hrybky. Naukovyi visnyk LNUVM i BT imeni S.Z. Hzhytskoho, 19(82), 36-40. doi: 10.15421/nvlvet8208 (in Ukrainian).

OECD (2017). Test No. 402: Acute Dermal Toxicity, OECD Guidelines for the Testing of Chemicals, Sec- tion 4, OECD Publishing, Paris. doi: $10.1787 / 9789264070585$-en.

OECD (1981). Test No. 410 "Repeated Dose Dermal Toxicity: 21/28-day Study”. doi: 10.1787/20745788.

Kosenko, M.V., Malyk, O.H., Kotsiumbas, I.Ia., Patereha, I.P., Chura, D.O. (1997). Toksykolohichnyi kontrol novykh zasobiv zakhystu tvaryn: Metodychni rekomendatsii. K. (in Ukrainian).

Kotsiumbas, I.Ia., Malyk, O.E., \& Patereha, I.P. (2006). Doklinichni doslidzhennia veterynarnykh likarskykh zasobiv. Lviv: Triada plius (in Ukrainian).

Todoriuk, V.B., Hunchak, V.M., Gutyj, B.V., Gufriy, D.F., Hariv, I.I., Khomyk, R.I. , \& Vasiv, R.O. (2018). Preclinical research of the experimental preparation "Ferosel T". Ukrainian Journal of Veterinary and Agricultural Sciences, 1(1), 3-9. doi: 10.32718/ujvas1-1.01. 